\title{
Mentorship Helps Mission-Driven Venture Thrive
}

\section{Kimberly Eddleston (Northeastern University)}

KEYWORDS: Entrepreneurship, Women, social entrepreneurship, mentors.

Vulnerable women living in Colombia are earning money and improving their lives through jewelry-making, thanks to Artyfactos. The company has found markets for the women's creations in the US and Europe, including some Macy's stores. In this interview with EIX Editor Kim Eddleston, Artyfactos Founder Angie Sanchez talks about the impact of mentors and accelerators on her venture's success.

\section{Read More}

Advice, Best Practices and Inspiration for Women Entrepreneurs(https://eiexchange.com/women)

Additional search terms: women, female founders, women business owners, opportunity, helping others while making money, empowerment, fighting poverty 